\title{
QUALITY OF FRESH-CUT AVOCADO (Persea americana Mill.) STORED UNDER DIFFERENT TEMPERATURES
}

\author{
Qualidade de abacates (Persea americana Mill.) minimally processados \\ armazenados sob diferentes temperaturas
}

\author{
Ana Carla Marques Pinheiro', Eduardo Valério de Barros Vilas Boas', Lucas Carvalho e Silva², \\ Alessandra de Paiva Alves ${ }^{3}$, Marcelo La Selva ${ }^{4}$, Adimilson Bosco Chitarra ${ }^{1}$
}

\begin{abstract}
The goal of this work was to evaluate the effect of different storage temperatures on the quality maintenance of fresh-cut 'Fortuna' avocado (Persea americana Mill.). The fruit was selected, washed and sanitized with sodium hypochlorite solution (190 ppm total residual chlorinee) for 15 minutes. After that, the tip was cut and the fruit was also cut in halves, peeled and the pit removed, manually. Then the halves were immersed in $0.5 \%$ calcium chlorite $+0.5 \%$ cysteine solution for 2 minutes, to avoid darkening and packed in rigid plastic covered with 20 micrometer thick plastic wrap (PVC film) with a permeability to $\mathrm{O}_{2}, \mathrm{CO}_{2}$ and water vapor of $15,000,80,000$ and $390 \mathrm{~cm}^{3} / \mathrm{m}^{2} /$ day, respectively. The product was stored under 3 different temperatures $0,5,10^{\circ} \mathrm{C}$ and evaluated at 5 different storege periods of $0,2,3,5$ and 6 days, in a randomized design in a $3 \times 5$ factorial. The storage of fresh-cut avocado at $5^{\circ} \mathrm{C}$ is the best alternative because it determines better maintenance of quality of the avocado. These presented lower darkening of pulp, better scores for appearance and acceptability, lower softening and polyphenoloxidase activity, in comparison to those stored at 0 and $10^{\circ} \mathrm{C}$. The fresh-cut avocados stored at $5^{\circ} \mathrm{C}$ presented a shelf life of 5 days, based, mainly on, appearance, score 7.3 , sited between the concepts "like moderately" and "like very much" on a hedonic scale of 9 points and $86 \%$ of acceptability, at the end of 5 days of storage.
\end{abstract}

Index terms: Appearance, acceptability, enzymes, firmness, avocado, Persea Americana.

\section{RESUMO}

Objetivou-se avaliar o efeito de diferentes temperaturas de armazenamento na manutenção da qualidade de abacates 'Fortuna' (Persea americana Mill.) minimally processados. Os frutos foram lavados e sanificados em solução de hipoclorito de sódio (190 ppm de cloro residual total) por 15 minutos. Posteriormente, efetuou-se a retirada da extremidade onde se insere o pedúnculo, o corte em metades, retirada do caroço e casca, manualmente. Em seguida, as metades foram imersas em solução com cloreto de cálcio $0,5 \%+$ cisteína $0,5 \%$ durante 2 minutos, para prevenção do escurecimento, e então acondicionadas em embalagens plásticas (PET) rígidas envoltas com filme (PVC) 20 micrometros de espessura e permeabilidade a $\mathrm{O}_{2}, \mathrm{CO}_{2}$ e vapor d'água de $15.000,80.000$ e $390 \mathrm{~cm}^{3} / \mathrm{m}^{2} /$ dia respectivamente. Em seguida, foram armazenadas em 3 diferentes temperaturas, $0,5,10^{\circ} \mathrm{C}$, as quais foram avaliadas em 5 diferentes tempos de armazenamento (0,2,3, 5 e 6 dias), seguindo um delineamento inteiramente casualizado fatorial 3 X 5 . O armazenamento a $5^{\circ} \mathrm{C}$ de abacates minimamente processados apresenta-se como a melhor alternativa, pois determinou melhor manutenção da qualidade dos abacates. Estes apresentaram, conjuntamente, menor escurecimento da polpa, melhores notas para aparência e aceitabilidade, menor perda da firmeza e atividade da polyphenol oxidase, diferindo-se dos armazenados a 0 e $10^{\circ} \mathrm{C}$. Os abacates minimally processados armazenados a $5^{\circ} \mathrm{C}$ apresentaram vida útil de 5 dias baseando-se, principalmente, na aparência nota 7,3, valor este situado entre os conceitos gostei moderadamente e gostei muito na escala hedônica de 9 pontos e $86 \%$ de aceitabilidade, ao final dos 5 dias de armazenamento.

Termos para indexação: Aparência, aceitabilidade, enzimas, firmeza, abacate, Persea americana.

(Received in september 28, 2006 and approved in may 16, 2007)

\section{INTRODUCTION}

The avocado (Persea americana Mill.) is a nutritious fruit, rich in unsaturated fatty acids and hydrosoluable vitamins, especially A and C, but its sugar content is low. The fruit could be recommended, as an energy food, for diabetic people (Swisher, 1988). It can be consumed in salads and/or as dessert, being served with sugar or even homogenized with milk. The largest world producer is Mexico, Brazil being in fourth place in the

\footnotetext{
${ }^{1}$ Agronomy Engineers, Doctors in Food Science - Departamento de Ciência dos Alimentos/DCA - Universidade Federal de Lavras/UFLA - Cx. P. 3037 37200-000 - Lavras, MG - anacarlamp@ufla.br; evbvboas@ufla.br

2Undergraduate in Agronomy - Departamento de Ciência dos Alimentos/DCA - Universidade Federal de Lavras/UFLA - Cx. P. 3037 - $37200-000$ Lavras, MG - lucaslcs2004@yahoo.com.br

${ }^{3}$ Undergraduate in Food Engineering - Departamento de Ciência dos Alimentos/DCA - Universidade Federal de Lavras/UFLA - Cx. P. 3037 - $37200-000$ -

Lavras, MG - alessandraufla@uol.com.br

${ }^{4}$ Food Engineer - Avenida João Pessoa, n 341, apto 04, CEP 90040-000, Porto Alegre-RS - mlsufla@gmai.com
} 
ranking, with a production, in 2005, of 173 thousand tons in an area of 12 thousand hectares. The world production is, approximately, 3.2 million tons and an area of 416 thousand hectares (FAO, 2005).

Minimally processed fruits ("fresh-cut") are defined as those that maintain their fresh state, in spite of having suffered physical alterations. They go through a selection process, washing, peeling and cutting until they approach a $100 \%$ usable product that is packaged in order to offer, to the consumers, freshness, convenience and nutritional quality (IFPA, 2007).

The quality of the fresh cut products is related to the maintenance of their sensorial characteristics and control of the contaminating microbiota, with maintenance of the quality of the intact fruit (Vilas Boas and Kader, 2001). That quality can be expressed through the indicators, that include nutritional, microbiological, technological and sensorial properties, such as appearance, aroma, flavor and texture (Martens and Baarseth, 1987).

The darkening and the softening constitute limiting factors to the commercialization of fresh cut fruits and vegetables (Vilas Boas and Kader, 2001). The appearance is the first factor that determines the acceptability or rejection of the foods. Therefore, the maintenance of the original color during the entire processing and storage of the foods is the largest and most difficult objective for the processors (Soliva et al., 2001; Almeida and Nogueira, 1995). The enzymatic darkening, catalized by the polyphenol oxidases (PPO) and peroxidases is one of the main problems in the preservation of the avocado pulp (Dorantes et al., 1998). PPO is an enzyme that, in the presence of oxygen, catalyzes the oxidation of phenolic substrates in quinones, these, later, are polimerized, forming brown, red or black pigments (Soliva et al., 2001). In the same way, the peroxidases present typical activity in the phenolic oxidation, using, however, hydrogen peroxide $\left(\mathrm{H}_{2} \mathrm{O}_{2}\right)$ as electron donor, also giving origin to the quinones, which once polimerized, give origin the compounds with dark coloration (Chitarra, 2000). Several methods have been used to inhibit the PPO activity in fruits and vegetables: chemical additives (Melo, Vilas Boas and Justo, 2009; Vilas Boas, Reis and Melo, 2009; Melo and Vilas Boas, 2006; Soliva et al., 2002; Soliva et al., 2001; Fujita et al., 1995), exclusion of $\mathrm{O}_{2}$ (Soliva et al., 2002; Siddiq et al., 1992), pH adjustment (Soliva et al., 2001; Soliva et al., 2002), cooling (Lozano et al., 1994) and thermal treatment. The cooling is the most economical method for the prolonged storage of fresh fruits and vegetables. The other methods for control of darkening are used as a complement to the lowering of the temperature. These methods, such as environmental control or modification, the use of wax on the surface of the products, chemical additives, among others, does not produce good results if they are not associated to the use of low temperatures (Chitarra and Chitarra, 2005). Flitsanov et al. (2000), working with storage of intact avocados under different temperatures observed that avocados stored at 6 and $8^{\circ} \mathrm{C}$ softened more quickly than those stored at 2 and $4^{\circ} \mathrm{C}$.

In function of the growth potential of the fresh cut fruit sector in Brazil, as well as the lack of studies, specifically on fresh cut avocado, in this work, the objective was to verify the effect of the use of different storage temperatures on the maintenance of quality of fresh cut avocados.

\section{MATERIALAND METHODS}

The fruits utilized were 'Fortune ' avacados with average diameter, weight, firmness and dry matter values of $9.17 \pm 0.7 \mathrm{~cm}, 611.78 \pm 66 \mathrm{~g}, 2.9 \pm 0.9 \mathrm{~N}$ and $19 \pm 2 \%$, respectively. The fruits were washed with detergent and soon afterwards stored for 12 hours at $10^{\circ} \mathrm{C}$ before the processing. Later, they were immersed, for 15 minutes, in hypochlorite solution with $190 \mathrm{ppm}$ of total residual chlorine, soon afterwards, the stalk insertion extremity was removed, the fruits halved longitudinally and the pit and peel manually removed. The halves (average weight and firmness values of $232.0 \mathrm{~g}$ and $3.4 \mathrm{~N}$ respectively) were immersed in solution of $0.5 \%$ calcium chlorite $+0.5 \%$ cysteine chlorhydrate for 2 minutes, according to Melo and Vilas Boas (2006), for prevention of the darkening and, later, were conditioned in rigid plastic (PET) containers, Galvanotek brand,(15, 12 and 5,5 cm of length, width and height respectively) wrapped with a 20 micron thick film (PVC) with an $\mathrm{O}_{2}, \mathrm{CO}_{2}$ and water vapor permeability of $15,000,80,000$ and $390 \mathrm{~cm}^{3} / \mathrm{m}^{2} /$ day respectively. The experiment was carried out in the Fruit and Vegetable Post Harvest Laboratory of the Food Science Department of the Federal University of Lavras/MG, following an entirely casualized layout, in $3 \times 5$ factorial corresponding to 3 storage temperatures $\left(0,5\right.$ and $\left.10^{\circ} \mathrm{C}\right)$ and five analysis periods $(0,2,3,5$ and 6 days of storage), with three repetitions, the experimental portion being made up of two halves. The sensorial evaluation was done, following a block layout, made up of 50 blocks (50 testers). The sensorial acceptability of the appearance was evaluated until the sixth day of storage $(0,2,3,5$ and 6 days) and that of flavor, was evaluated until the third day $(0,2$ and 3 days), following which, there was no response aboutthe microbiological quality of the product. The following analyses in the evaluation periods took place: pulp color 
(value $\mathbf{L} *$ ): determined, in four distinct regions in a same half, using a Minolta, model CR 400 Chroma Metercolorimeter, measuring the $\mathrm{L} *$ value that varies from white ( value $=100$ ) to black (value $=0$ ); sensorial analysis of appearance acceptance, flavor and even purchase intention: accomplished through the Consumers Test (Meilgaard et al., 1999) in a supermarket of the municipal district of LavrasMG, using 50 testers, in other words, potential consumers. The appearance and flavor of the product was evaluated, using a mixed nine point structured hedonic scale (9extremly liked; 1 - extremly disliked) and the purchase intention in which the testers responded on the evaluation chart if they would or would not buy the product; polyphenol oxidase (PPO) and peroxidase (PER) enzyme activity: the extraction of PPO and PER was carried out according to the method described by Matsumo and Uritami (1972). The frozen tissue was homogenized in a polytron, with $0.05 \mathrm{M}, \mathrm{pH} 7.0$ phosphate buffer and immediately filtered in organza. The obtained homogenate was centrifuged for $10 \mathrm{~min}$ at $5,000 \mathrm{rpm}$ at $0^{\circ} \mathrm{C}$ temperature. The resulting supernatant was used for the enzymatic activity determination. The determination of PPO was done according to the method described by Teisson (1979). An $1 \mathrm{~mL}$ aliquot of enzymatic extract was combined with 3.6 $\mathrm{mL}$ of $0.1 \mathrm{M}, \mathrm{pH} 7$ phosphate buffer and $0.1 \mathrm{~mL}$ of catechol $10 \mathrm{~mm}$. The obtained solution was incubated during 30 min at $30^{\circ} \mathrm{C}$, and the reaction was interrupted by the addition of $0.1 \mathrm{~mL}$ of $2 \mathrm{~N}$ perchloric acid. The enzymatic activity was expressed as a unit (enzymatic activity capable to alter 0.0001 of absorbance at $395 \mathrm{~nm}$ ) of gram of fresh pulp per minute $\left(\mathrm{UAE} \cdot \mathrm{g}^{-1} \cdot \mathrm{min}^{-1}\right)$. The determination of the PER activity was carried out according to the method described by Matsumo and Uritani (1972). A 3mL aliquot of enzymatic extract was pipeted over a solution containing $5 \mathrm{~mL}$ of citrate phosphate buffer $0.02 \mathrm{M}, \mathrm{pH} 5,0.5 \mathrm{~mL}$ of hydrogen peroxide and $0.5 \mathrm{~mL}$ of guaiacol. The solution was incubated at $30^{\circ} \mathrm{C}$ for $5 \mathrm{~min}$, and the reaction interrupted by the addition of $1 \mathrm{~mL}$ of $30 \%$ sodium bisulfite. The activity of the PER enzyme was expressed as a unit (activity capable to alter 0.001 of absorbance at $470 \mathrm{~nm}$ ) per gram of fresh pulp per minute (UAE. ${ }^{-1} \cdot \mathrm{min}^{-1}$ ).

Firmness: determined with the aid of a texture analyzer model TA.X2i, using an $8 \mathrm{~mm}$ diameter $(\mathrm{P} / 6 \mathrm{~N})$ stainless steel probe, that measured the penetration force in the fruit pulp, in four places in a same avocado half, at a speed of $10 \mathrm{~mm} / \mathrm{s}$ and at a maximum of penetration distance of $10 \mathrm{~mm}$, these values being previously fixed. The firmness of the fruits was expressed in Newtons $(\mathrm{N})$;

The data was first analyzed through variance analysis (ANOVA) and, later regression and/or Tukey test, using the statistical program SISVAR version 4.0 (Ferreira, 2000).

\section{RESULTSAND DISCUSSION}

There was an interactive effect between the temperature and storage time factors on the $\mathrm{L} *$ value (color of the pulp), appearance and acceptability of the avocado halves (Illustrations 1, 2 and 3). In Figure1, a decrease is observed in the $\mathrm{L} *$ value, indicating that there was surface darkening of the fruit pulp, in spite of the temperatures used during storage. The fruits stored at $10^{\circ} \mathrm{C}$ presented, on average, lower $\mathrm{L} *$ values that the others, in other words, higher pulp darkening, after the 3rd day of storage.

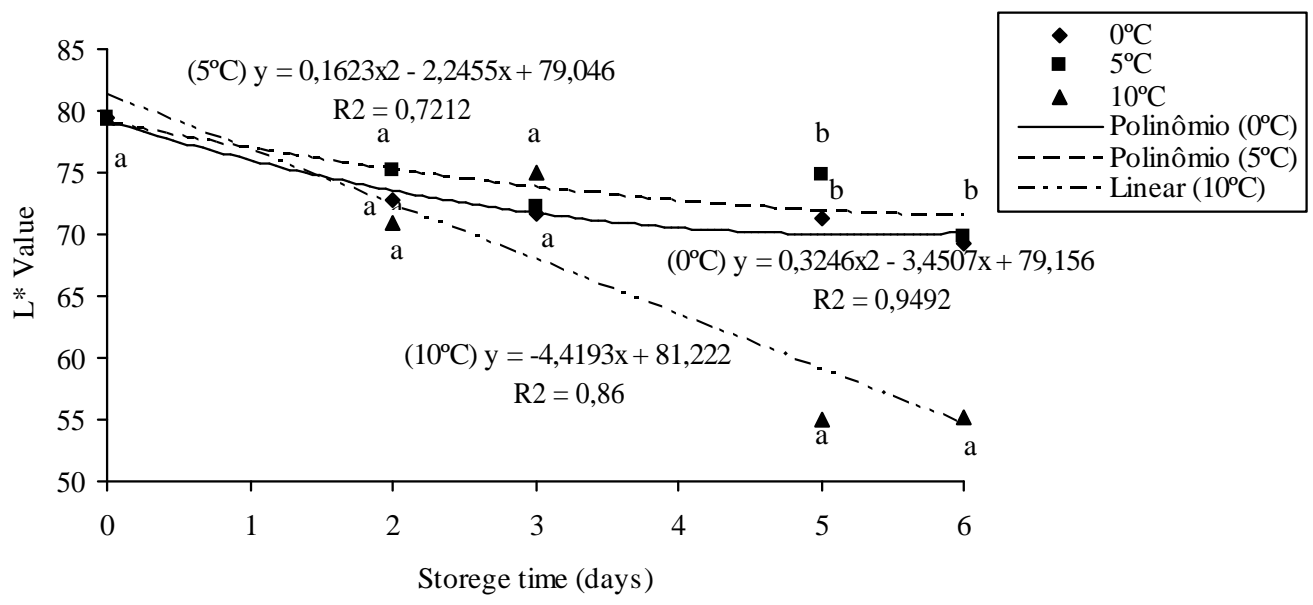

Figure 1 - Color of pulp surface ( $\mathrm{L}^{*}$ value) of fresh cut avocados during storage, under different temperatures. Points on the vertical followed by the same letter are equal among themselves by the Tukey Test $(\mathrm{p}<0,05)$. 
On analysis of Figures 2 and 3 it can be noticed that after only the 2 nd day of storage, there is an effect of the temperatures on the appearance and purchase intention (PI) of the product. The fruits stored at $5^{\circ} \mathrm{C}$ presented, on average, better appearance and PI, followed by those stored at $0^{\circ} \mathrm{C}$ and $10^{\circ} \mathrm{C}$, on the $2 \mathrm{nd}, 3 \mathrm{rd}$ and 5 th days. On the 6 th day, the fruits under $0^{\circ} \mathrm{C}$ presented, on average, better appearance and PI, followed by the fruits stored at $5^{\circ} \mathrm{C}$ and $10^{\circ} \mathrm{C}$, respectively. The fruits under $5^{\circ} \mathrm{C}$ presented, on average, from 0 to the 5 th day of storage, scores between 8.53 and 7.53 , located between the concepts "I liked very much" and "I moderately liked", and PI from $92 \%$ to $86 \%$, showing $5^{\circ} \mathrm{C}$ to be the best temperature for the storage of this product. Such results are agree with those of pulp color, which show that the fruits stored at $5^{\circ} \mathrm{C}$ and $0^{\circ} \mathrm{C}$ present better coloration (higher $\mathrm{L} *$ value).

Freire et al. (2002), working with fresh cut hydroponic lettuce cv. Regina observed that the product stored at $2^{\circ} \mathrm{C}$ presented better sensorial quality than that at $10^{\circ} \mathrm{C}$, this quality measured through the color, intensity of central rib and border darkening, global impression, among others. These results agree with those presented in the present work, which verified the best sensorial quality, appraised through the acceptance test, of the avocados stored at $5^{\circ} \mathrm{C}$ followed by those at $0^{\circ} \mathrm{C}$. The

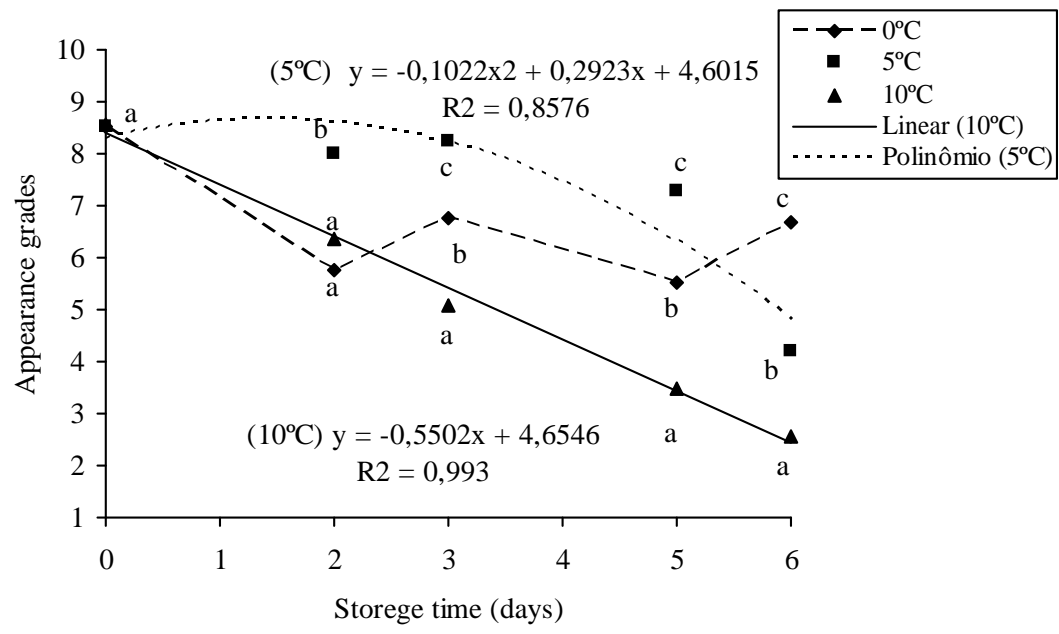

Figure 2 - Appearance of fresh cut avocados during storage under different temperatures. Points on the vertical followed by the same letter are the same among themselves by the Tukey Test $(\mathrm{p}<0,05)$.

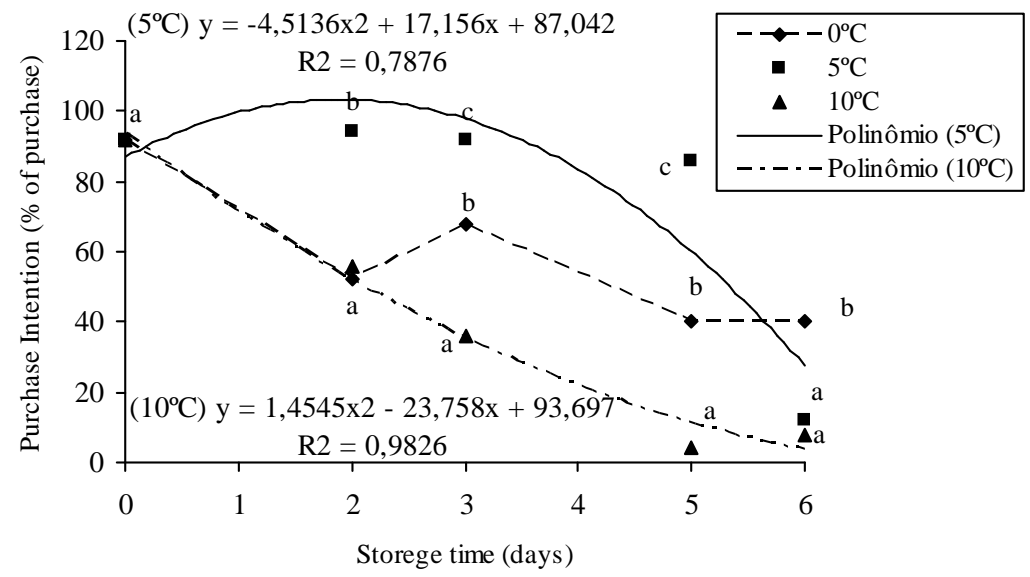

Figure 3 - Purchase intention of fresh cut avocados during storage under different temperatures. Points on the vertical followed by the same letter are the same among themselves by the Tukey Test $(\mathrm{p}<0,05)$. 
appropriate use of low temperatures in the storage of vegetables leads to a reduction in the activity of several enzymes responsible for the deterioration of the product, being effective in the shelf life extension and quality maintenance of vegetables, be them in natura or minimally processed.

The flavor was evaluated until the third day of storage, having only been influenced by the storage time factor (Illustration 4). A decrease was noticed in the flavor scores until the 3rd day, although the fruits on the third day still presented, on average, score 6.2 , located between the concepts "I moderately liked" and "I slightly liked". There was no significant effect of the storage temperatures on the flavor.

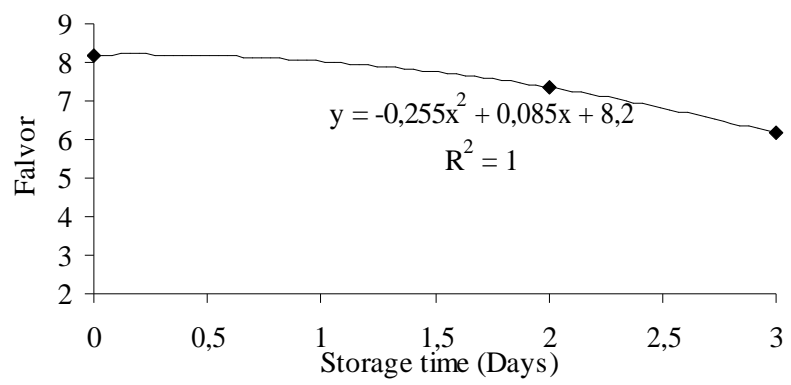

Figure 4 - Average flavor values during storage of fresh cut avocados stored under different temperatures.

The PPO activity was influenced by the time and storage temperature factors, separately, while the PER activity, only by the storage time(Table 1 and Figures 5 and 6).

Table 1 - Average values of polyphenol oxidase (PPO) activity of avocados, fresh cut and stored under different temperatures, followed by the Tukey Test $(p<0,05)$.

\begin{tabular}{cc}
\hline $\begin{array}{c}\text { Storage } \\
\text { Temperature }\end{array}$ & PPO Activity $\left(\mathrm{UAE} \cdot \mathrm{g}^{-1} \cdot \mathrm{min}^{-1}\right)$ \\
\hline $0^{\circ} \mathrm{C}$ & $328.37 \mathrm{ab}$ \\
$5^{\circ} \mathrm{C}$ & $308.11^{\mathrm{a}}$ \\
$10^{\circ} \mathrm{C}$ & $369.54 \mathrm{~b}$
\end{tabular}

Averages followed by the same letter, in the columns, are equal among themselves by the Tukey Test $(\mathrm{p}<0.05)$

It is observed in Table 1, that there is a higher PPO activity in the fruits stored at $10^{\circ} \mathrm{C}$, differing statistically ( $\mathrm{p}$ $<0.05$ ) from those under $5^{\circ} \mathrm{C}$ (lower activity). The avocado halves stored at $0^{\circ} \mathrm{C}$ presented PPO activity statistically the same to those under 5 and $10^{\circ} \mathrm{C}$. Those results agree

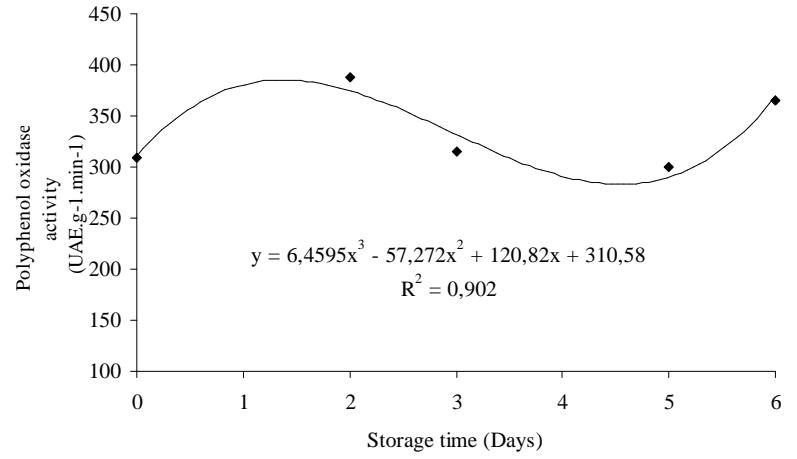

Figure 5 - Activity of polyphenol oxidase (UAE. $\mathrm{g}^{-1} \cdot \mathrm{min}^{-1}$ ) of fresh cut avocados during storage, under different temperatures.

with the results of the $\mathrm{L} *$ value (pulp color). Soliva et al. (2001), evaluating the effect of different chemicals and environments on the prevention of darkening of avocado purée stored under refrigeration $\left(4^{\circ} \mathrm{C}\right)$, observed that purées, without any chemical treatment and stored under a normal environment presented higher pulp darkening and higher PPO activity, behavior similar to that verified in the present work.

The PPO activity presented, on average, an increase until the 2 nd day of storage with a subsequent decline to the 5th day and quick ascension to the 6th day. These results agree with that of the $\mathrm{L} *$ value (pulp surface color) which points to an increase in the darkening of the pulp during storage (Illustration 1).

The oxidation of phenolic compounds can also result from the peroxidase (PER) activity, that is related, for instance, to alterations in the color and to the development of strange aromas during storage. Thus, a high rate of enzymatic activity implies a high deterioration potential of the sensorial characteristics of the fruit, reducing their shelf life (Lima et al., 2002). According to Vilas Boas et al. (2007) the peroxidase also contributes, in an indirect way, to the darkening of fresh cut products, destruturing the cellular membranes, reducing their selective permeability; even promoting chain reactions that lead to free radical formation that can cause damage to the organelles and membranes, able to alter the sensorial characteristics of the product. Therefore, a high rate of enzymatic activity implies a high deterioration potential of the sensorial characteristics of the fruit, reducing their shelf life (Lima et al., 2002). The peroxidase activity increased with the storage of the avocados fresh cut (Illustration 6). That increase might have contributed to 


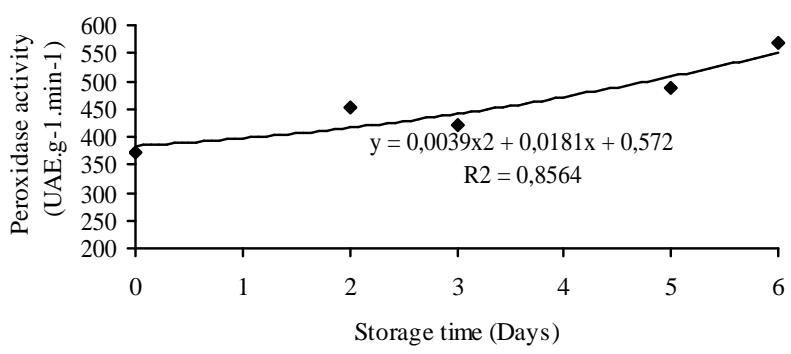

Figure 6 - Peroxidase activity $\left(\mathrm{UAE} \cdot \mathrm{g}^{-1} \cdot \mathrm{min}^{-1}\right.$ ) of fresh cut avacados during storage, under different temperatures.

the modification of the flavor and to the darkening occurrence in the fruit pulp during the storage, mainly in those stored under $10^{\circ} \mathrm{C}$.

Melo and Vilas Boas (2006), working with the application of different chemical for the prevention of the darkening of fresh cut 'Apple ' bananas also observed an increase of the PER activity during storage, in spite of the chemical treatments.

There was a significant effect of the interaction between the temperature and storage time factors on fruit firmness (Illustration 7). An accentuated firmness decrease was observed in the avocado halves under $0^{\circ} \mathrm{C}$ followed by those at $10^{\circ} \mathrm{C}$. The halves stored at $5^{\circ} \mathrm{C}$ presented higher pulp firmness stability the during storage. The products submitted to $10^{\circ} \mathrm{C}$ presented higher loss of firmness probably due to their presenting more intense metabolic activity than those at $5^{\circ} \mathrm{C}$. Those stored at $0^{\circ} \mathrm{C}$, although having a less intense metabolism, might have suffered some damage process in the cellular membranes, such as change of state of the their lipids caused by the low temperature, affecting the cellular integrity and, consequently, the firmness. It can also be observed, in Figure 7, that on the 3 rd day of storage the product stored the $0^{\circ} \mathrm{C}$ presented lower firmness than the fruits under $10^{\circ} \mathrm{C}$ however, these presented a firmness statistically equal to the product at $5^{\circ} \mathrm{C}$. Starting from the $3 \mathrm{rd}$ day of storage the halves stored at $5^{\circ} \mathrm{C}$ presented, on average, higher firmness than the others $\left(0\right.$ and $\left.10^{\circ} \mathrm{C}\right)$, which presented statistically equal firmness until the end of the storage.

Flitsanov et al., (2000), working with storage of intact avocados under different temperatures, observed that during four weeks of storage under low temperatures ( 2 and $4^{\circ} \mathrm{C}$ ) there was an insignificant decrease in the firmness of the fruits, which presented firmness equal to $89.2 \mathrm{~N}$ and $79.2 \mathrm{~N}$, respectively, until the fourth week of storage, while, the fruits under higher storage temperatures $\left(6\right.$ and $8^{\circ} \mathrm{C}$ ) altered their firmness more significantly to 12.5 $\mathrm{N}$ and $10.9 \mathrm{~N}$, respectively, at the end of this period. Such results, demonstrate that the lowering of the temperature is efficient in the maintenance of the firmness and, consequently, in the increase of the postharvest life of vegetables in natura, as long as the low temperature tolerance limits for each species and/or cultivar are respected, avoiding the damage caused by the cold.

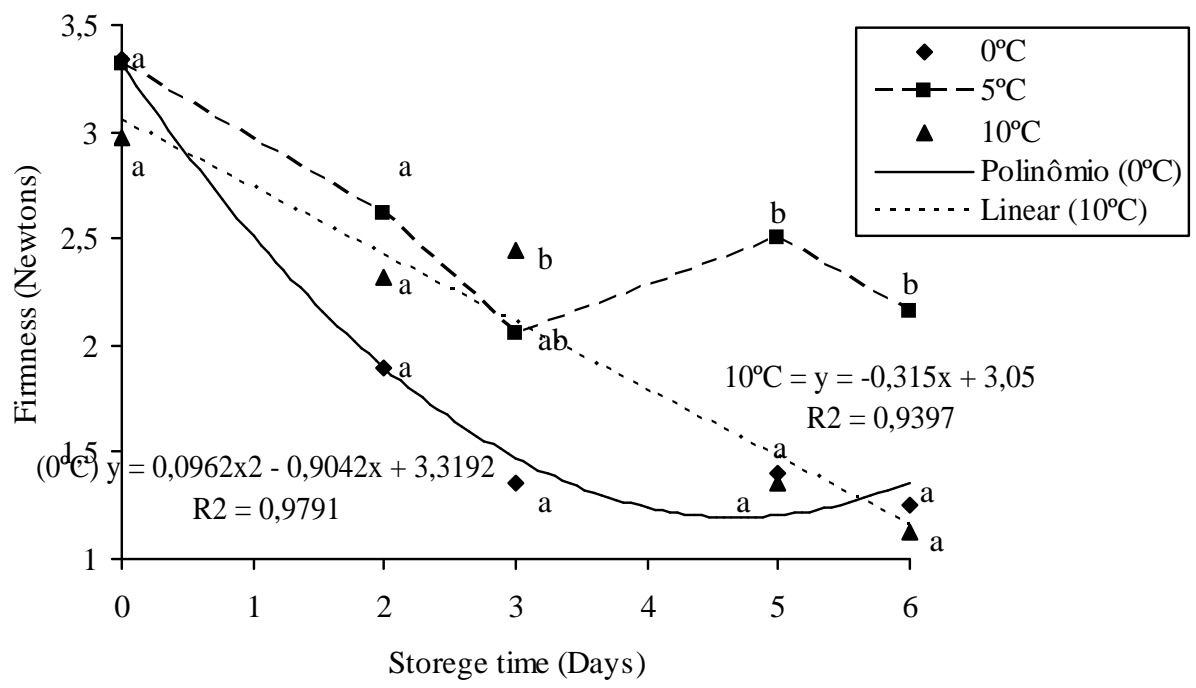

Figure 7 - Firmness $(\mathrm{N})$ of fresh cut avocados during storage, under different temperatures. Points on the vertical followed by the same letter are the same among themselves by the Tukey Test $(\mathrm{p}<0,05)$. 


\section{CONCLUSIONS}

The storage of fresh cut 'Fortuna ' avocados, submitted to the application of $0.5 \%$ cysteine chlorhydrate $+0.5 \%$ calcium chlorite, at $5^{\circ} \mathrm{C}$ is the most appropriate for determining better appearance and purchase intention, higher firmness maintenance and lower polyphenol oxidase activity, while storage at $10^{\circ} \mathrm{C}$ is not recommended due to causing changes in the pulp surface color, bad appearance and low purchase intention.

'Fortuna ' avocados, frech cut, submitted to the application of $0.5 \%$ cysteine chlorhydrate $+0.5 \%$ calcium chlorite and stored at $5^{\circ} \mathrm{C}$ possess a shelf life of 5 days based on the scores above 7.0 for appearance and purchase intention above $86 \%$ at the end of this period.

\section{ACKNOWLEDGEMENTS}

To Conselho Nacional de Desenvolvimento Científico e Tecnológico-CNPq, Fundação de Amparo à Pesquisa do Estado de Minas Gerais-FAPEMIG and Coordenação de Aperfeiçoamento de Pessoal de Nível Superior-CAPES, Brazilian government entities, promoters of scientific and technological development.

\section{BIBLIOGRAPHICAL REFERENCES}

ALMEIDA, M. E. M.; NOGUEIRA, J. N. The control of polyphenol oxidase activity in fruits and vegetables. Plant Foods for Human Nutrition, v. 47, p. 245-256, 1995.

CHITARRA, M. I. F. Processamento mínimo de frutas e hortaliças. Lavras: UFLA/FAEPE, 2000. 119 p.

CHITARRA, M. I. F.; CHITARRA, A. B. Pós-colheita de frutas e hortaliças: fisiologia e manuseio. 2. ed. Lavras: UFLA, 2005. $785 \mathrm{p}$.

DORANTES, L.; PARADA, L.; ORTIZ, A.; SANTIAGO, T.; CHIRALT, A.; BARBOSA-CÁNOVAS, G. Effect of anti-browning compounds on the quality of minimamally processed avvados. Food Science and Technology International, London, n. 4, p. 107-113, 1998.

FERREIRA, D. F. Análises estatísticas por meio do SISVAR para Windows, versão 4.0. In: REUNIÃO ANUAL BRASILEIRA DA SOCIEDADE INTERNACIONAL DE BIOMETRIA, 45., 2000, São Carlos. Resumos... São Carlos: UFSCAR, 2000. p. 235.

FREIRE JÚNIOR, M.; DELIZA, R.; CHITARRA, A. B. Alterações sensoriais em alface hidropônica cv. Regina minimally processada e armazenada sob refrigeração. Horticultura Brasileira, Brasília, v. 20, n. 1, p. 63-66, 2002.

FLITSANOV, U.; MIZRACH, A.; LIBERZON, A.; AKERMAN, M.; ZAUBERMAN, G. Measurement of avocado softening at various temperatures using ultrasound. Postharvest Biology and Technology, Amsterdam, v. 20, p. 279-286, 2000.

FOOD AGRICULTURAL ORGANIZATION. Statistical database. 2005. Disponível em: <www.apps.fao.org $\lambda_{-}$ Acesso em: 5 jan. 2006.

FUJITA, S.; BIN SAARI, N.; MAEGAVA, M.; TETSUKA, T.; HAYASHI, N.; TONO, T. Purification and poperties of polyphenol oxidase from cabbage (Brassica oleracea L.). Journal of Agricultural and Food Chemistry, Easton, v. 43, n. 5, p. 1138-1142, 1995.

\section{INTERNATIONAL FRESH-CUT PRODUCE} ASSOCIATION. Disponível em: <htitp:/Www.fresh cuts.org>. Acesso em: 10 abr. 2007.

LIMA, M. A. C. de; LIMA, C. de; ALVES, R. E.; ASSIS, J. S.; FILGUEIRAS, H. A. C.; COSTA, J. T. Aparência, compostos phenolico e enzimas oxidativas em uva 'Itália' sob influência do cálcio e do armazenamento refrigerado. Revista Brasileira de Fruticultura, Cruz das Almas, v. 24, n. 1, p. 39-43, abr. 2002.

LOZANO, J. E.; DRUDIS, R.; IBARZ, A. Enzimatic browning in apple pulps. Journal of Food Science, Chicago, v. 59, n. 3, p. 564-567, 1994.

MARTENS, M.; BAARSETH, P. Postharvest quality changes, sensory quality. In: WEICHMANN, J.

Postharvest physiology of vegetables. New York: Dekker, 1987. p. 597.

MATSUMO, H.; URITAMI, I. Physiological behavior of peroxidase enzymes in sweet potato root tissue injured by cutting or black root. Plant Cell and Physiology, v. 13, n. 6, p. 1091-1101, 1972.

MEILGAARD, M.; CIVILLE, G. V.; CARR, B. T. Sensory evaluation techniques. 3. ed. London: CRC, 1999. $387 \mathrm{p}$. 
MELO, A. A. M., VILAS BOAS E. V. B. de, JUSTO, C. F. Uso de aditivos químicos para a conservação póscolheita de banana 'maçã' minimally processada. Ciência e Agrotecnologia. V. 33, n.1, p.228-236, 2009.

MELO, A. A. M.; VILAS-BOAS, E. V. B. de. Inibição do escurecimento enzimático de banana 'Maçã' minimally processada. Ciência e Tecnologia de Alimentos, Campinas, v. 26, n. 1, p. 110-115, 2006.

SIDDIQ, M.; SINHA, N. K.; CASH, J. N. Caracterization of polyphenoloxidase from Stanley plums. Journal of Food Science, Chicago, v. 57, n. 5, p. 1177-1179, 1992.

SOLIVA, R. C.; ELEZ, P.; SEBATIÁN, M.; MARTIN, O. Evaluation of browning effect on avocado purée preserved by combined methods. Innovative Food Science and Emerging Technologies, n. 1, p. 261-268, 2001.

SOLIVA, R. C.; ELEZ, P.; SEBATIÁN, M.; MARTIN, O. Kinetics of polyphenol oxidase activity inhibition and browning of avocado purée preserved by combined methods. Journal of Food Engineering, Essex, v. 55, p. 131-137, 2002.
SWISHER, E. H. Avocado oil from food use to skin care. Journal of American Oil Chemistries Association, Chicago, v. 65, p. 1704-1706, 1988.

TEISSON, C. Lê brunissement interne de I'ananás: IHistorique: II-Material et méthodos. Fruits, v. 34, n. 4, p. 245-281, 1979.

VILAS-BOAS, E. V. de B.; KADER, A. A. Effect of 1$\mathrm{MCP}$ on fresh-cut fruits. Perishables Handling Quarterly, n. 108, p. 25, 2001.

VILAS BOAS, E. V. de B., REIS, C. M. F., MELO, A. A. M. Uso de misturas químicas para a manutenção da firmeza de banana 'prata' minimally processada. Ciência e Agrotecnologia. V.33, n.1, p.237-244, 2009.

VILAS-BOAS, E. V. de B.; VILAS-BOAS, B. M.; GIANONI, J. A.; RESENDE, J. M. Tendências na área de processamento mínimo de frutas e hortaliças: avanços tecnológicos. In: SIMPÓSIO BRASILEIRO DE PÓS-COLHEITA DE FRUTAS, HORTALIÇAS E FLORES, 2007, Viçosa. Resumos... Viçosa: UFV, 2007. p. 109-120. 